\title{
Effects of COVID-19 lockdown on the dietary habits and lifestyle in a population in southern Spain: a cross-sectional questionnaire
}

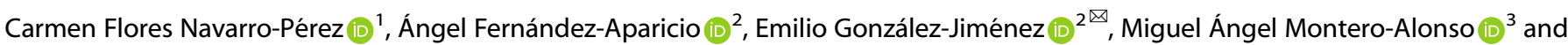 \\ Jacqueline Schmidt-RioValle ${ }^{2}$
}

(c) The Author(s), under exclusive licence to Springer Nature Limited 2021

\begin{abstract}
BACKGROUND/OBJECTIVE: Few studies have assessed the effect of lockdown on physical activity and eating behaviours in a population from the Autonomous Community of Andalusia in southern Spain. The aim of our study was to describe the effect of COVID-19 pandemic home lockdown on eating habits and lifestyle in the Andalusian population.

SUBJECTS/METHODS: A cross-sectional observational study was carried out on a population from southern Spain, Andalusian population. An online questionnaire was shared through social networks and snowball sampling. A total of 1140 people filled in the questionnaire. The questionnaire consisted of 34 items classified into three sections: sociodemographic data, work and leisure activities and questions on food consumption. Each item offered pre- and post-lockdown information.

RESULTS: The participants were classified into three age groups: 18-35, 36-65 and over 65. Statistically significant differences were found between the three groups, with the younger age group undergoing greater changes, increasing their physical activity and consumption of fresh food, and decreasing both their consumption of fast food at home and alcohol intake.

CONCLUSIONS: These findings suggest that, in the current social and health crisis, the citizens of southern Spain have become aware of the importance of maintaining an appropriate lifestyle to remain healthy, particularly the younger population with less well-consolidated habits.
\end{abstract}

European Journal of Clinical Nutrition (2022) 76:883-890; https://doi.org/10.1038/s41430-021-01034-w

\section{INTRODUCTION}

On 31 December 2019, a cluster of cases of SARS-CoV-2 viral pneumonia, referred to as COVID-19, was reported in the Chinese region of Wuhan [1]. With 161,237 confirmed cases and 6000 deaths [2], in March 2020, the World Health Organisation (WHO) declared a global pandemic [1].

In Spain, on 14 March 2020, to curb the increase in cases and the collapse of the healthcare system, a state of alarm was declared [3]. This declaration obliged the entire Spanish population to remain at home, allowing them to go out only to buy basic products, with the exception of people working jobs classified as essential. Initially, 15 days of house lockdown was imposed, which was eventually extended to 50 days. The entry into force of this lockdown motivated a social urgency to hoard food and household supplies to provide for homes in the days after 14 March. This was characterised by the compulsive purchase of pulses, beer and hygiene articles, resulting in shortages of basic products [4].

Numerous studies reflect the appearance of stress in people as a result of the lockdown $[5,6]$. In turn, a relationship has been found between situations of stress and uncertainty, and the consumption of hyperpalatable foods $[7,8]$. The first published data on consumption in the initial weeks of the lockdown and the weeks prior to it report a disproportionate increase in the purchase of food, with some non-perishable foodstuffs even increasing by $100 \%$ compared to the same month of the previous year [4, 9-11]. In this context, the WHO published guidelines on healthy eating [12] with the intention of preventing further negative effects of the pandemic deriving from an unhealthy diet, such as overweight and obesity, which are involved in the development of non-communicable diseases [13].

In addition, the WHO also published recommendations highlighting the importance of regular physical activity, its benefits for the body and mind, as well as its involvement in lower morbidity and mortality rates [14].

The first published studies warned, as expected, of changes in eating habits, including increased snacking, a greater number of meals consumed and changes in the weight of the participants and their physical activity levels, with two distinct trends; on the one hand, there were many who decreased their daily exercise $[15,16]$, while there was also a significant number of people who increased their physical activity over this period [17]. These habit changes depended largely on age. In this sense, in the area of

${ }^{1}$ Department of Nursing, Faculty of Nursing, Physiotherapy and Podiatry, University of Seville, 41009 Seville, Spain. ${ }^{2}$ Department of Nursing, Faculty of Health Sciences, University

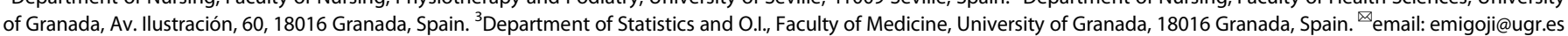


Developmental Psychology there are three major stages in adulthood: the youth stage, between approximately 20 and 40 years of age; the mature stage, between 40 and 65 , and finally the over $65 \mathrm{~s}$. The first stage is a period characterised by the appearance of a certain independence from the family, including a period of higher education and incorporation into the world of work. This decreases available time, and food is pushed into the background. The second stage is based on assuming and overcoming responsibilities, as well as social commitments, developing a certain emotional and work stability. The older stage is characterised by more rigid thinking, with less flexibility and greater rejection of changes involve in altered routines, as well as the cessation of working activity $[18,19]$. In Spain, people generally retire between 65 and 67 years of age [20].

Despite the volume of research published so far, few studies have evaluated the effect of lockdown on the physical activity and eating behaviours of the population from the Autonomous Community of Andalusia, in southern Spain. The aim of our work is, therefore, to describe the effect of COVID-19 pandemic home lockdown on the dietary habits and lifestyle of the Andalusian population, to prevent any negative impact of future outbreaks and subsequent lockdown measures.

\section{MATERIALS AND METHODS \\ Study design}

A cross-sectional observational study was carried out on a population from southern Spain, Andalusian population. Access was provided to an anonymous online questionnaire, which was active from 21 April (the sixth week of lockdown) until 2 May 2020, coinciding with the start of the lockdown de-escalation in Spain. The questionnaire was shared via social networks such as Instagram, Facebook, WhatsApp, virtual classrooms in which the researchers themselves were teaching, as well as by email, making snowball sampling possible. The questionnaire could be completed using any mobile device, tablet or computer. In addition, the number of days the participants had been confined to their homes, from the start of lockdown to the time they filled in the survey, was taken into account.

\section{Population}

The study population consisted of adults of 18 years of age or above, who used digital technology. The start of the questionnaire included a brief description of the purpose of the survey, information about the researchers responsible and the fact that the data collected would be both anonymous and confidential. Filling in the questionnaire was completely voluntary. In addition, the participants were able to leave the study at any time before submitting the survey. Responses were saved only when the submit button was clicked.

\section{Data collection}

The data were collected by means of a structured self-administered questionnaire, created on the Google Form platform. This questionnaire collected the questions to be answered sequentially and according to the scenarios 'before' and 'during' lockdown. It included 34 items and was divided into three main sections, organised as follows: one section on sociodemographic data; a second section containing questions about general habits, work and leisure activities; and finally, questions to determine variation in food consumption. The sociodemographic information collected included the variables age, sex, educational level, place where the lockdown was taking place, people with whom the participants were living at that time, information on the home they were confined to, their employment situation and the need to go out to work, as well as changes in financial income and body weight. The second section included questions on sleep habits and physical activity levels. The items referring to eating habits were: eating schedules and the number of meals/day, snacking between meals, consumption of ultra-processed food groups, fast food at home and the consumption of fresh food. Finally, we included questions aimed at investigating changes in the frequency of food consumption, with the intention of finding out whether the participants had increased, decreased or maintained their habits, for which we presented the foods organised into rows with four possible response options: no consumption, more, less or the same level. These foods included beverages such as soft drinks, stimulant drinks and alcohol.

\section{Data analysis}

The participants were divided into three groups according to their age; a first group of participants aged between 18 and 35, a second group between 36 and 65 and, finally, those over 65 years of age, according to the classification of the Spain's National Institute of Statistics [21]. Quantitative variables were analysed using a one-way ANOVA and qualitative variables were analysed using a $x^{2}$ test, both with a significance of 0.05 . Odds ratios were calculated using binary logistic regression analysis with dietary assessment (less or the same vs. more) as the dependent variable (confidence intervals at 95\%). The first step included models evaluating the relationship between each determinant and the assessment of food, less or the same versus more and the corresponding odds ratio, adjusted for the following variables: modified weight, degree of physical activity, amount of food and modified sleep. In the second step, the odds ratios were adjusted for sex and educational level. The normality of the distributions was checked using the Kolmogorov-Smirnov test. The significance level was $p<0.05$. All of the analyses were performed with version 24 of the SPSS software package (IBM, Armonk, NY, USA).

\section{RESULTS}

Table 1 shows the sociodemographic characteristics of the participants classified into three age groups: 18-35, 36-65 and over 65 years of age. A total of 1140 people participated, all of whom were of legal age. Highly significant statistical differences $(p<0.001)$ were found between the three age groups in relation to the number of cohabitants, leaving the home to go to work and the reduction of income during lockdown.

In relation to the habits of the participants (Table 2 ), statistically significant differences were found $(p<0.001)$ and $(p<0.05)$, in all the items presented between the different age ranges. In relation

Table 1. Sociodemographic characteristics of the participants by age group.

\begin{tabular}{|c|c|c|c|c|}
\hline Variables & 18-35 years & $36-65$ years & $>65$ years & Total \\
\hline $\begin{array}{l}\text { Days of } \\
\text { lockdown (mean } \\
\pm S D \text { ) }\end{array}$ & $39.4 \pm 7.10$ & $37.7 \pm 7.58$ & $41.7 \pm 5.87$ & $\begin{array}{l}38.7 \pm \\
7.35\end{array}$ \\
\hline \multicolumn{5}{|l|}{$\operatorname{Sex}^{a} p=0.311$} \\
\hline Woman & $471(55.8 \%)$ & $362(42.9 \%)$ & $11(1.3 \%)$ & 844 \\
\hline Man & $143(49.7 \%)$ & $138(47.9 \%)$ & $7(2.4 \%)$ & 288 \\
\hline \multicolumn{5}{|l|}{ Studies $^{b} p=0.283$} \\
\hline Not higher & $260(51.8 \%)$ & $233(46.4 \%)$ & $9(1.8 \%)$ & 502 \\
\hline Higher & $360(56.4 \%)$ & $269(42.2 \%)$ & $9(1.4 \%)$ & 638 \\
\hline \multicolumn{5}{|c|}{ No. of people living together $p<0.001$} \\
\hline Alone & $42(35 \%)$ & $75(62.5 \%)$ & $3(2.5 \%)$ & 120 \\
\hline With others & $578(56.7 \%)$ & $427(41.9 \%)$ & $15(1.5 \%)$ & 1020 \\
\hline \multicolumn{5}{|c|}{ House $m^{b} p=0.741$} \\
\hline$<60$ & $46(58.2 \%)$ & $33(41.8 \%)$ & 0 & 79 \\
\hline $61-90$ & $227(54.4 \%)$ & $184(44.1 \%)$ & $6(1.4 \%)$ & 417 \\
\hline$>91$ & $347(53.9 \%)$ & $285(44.3 \%)$ & $12(1.9 \%)$ & 644 \\
\hline \multicolumn{5}{|c|}{ During lockdown, income has been reduced ${ }^{c} p<0.001$} \\
\hline Yes & $316(57.0 \%)$ & $236(42.6 \%)$ & $2(0.4 \%)$ & 554 \\
\hline No & $276(51.4 \%)$ & $248(46.2 \%)$ & $13(2.4 \%)$ & 537 \\
\hline \multicolumn{5}{|c|}{ Due to your working situation, do you have to leave home to go to work? $p<0.001$} \\
\hline Yes & $108(43.5 \%)$ & $139(56.0 \%)$ & $1(0.4 \%)$ & 248 \\
\hline No & $512(57.4 \%)$ & $363(40.7 \%)$ & $17(1.9 \%)$ & 892 \\
\hline
\end{tabular}

${ }^{a}$ The figures do not coincide because 8 respondents preferred not to answer the sex question.

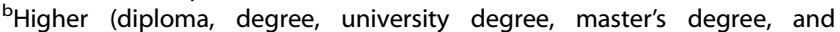
doctorate) and not higher (from primary studies to baccalaureate, including vocational training).

'The figures do not coincide because there were 49 respondents who preferred not to answer the income reduction question. 
to weight change during lockdown, more than half of the participants reported that their weight changed over this period.

In terms of frequency of food consumption (Tables 3-5), statistically significant differences were found $(p<0.001$ and $p<$ 0.05 ) with respect to age ranges for cereals and derivatives, both refined and wholemeal, sweets and pastries, potatoes, pulses, nuts, milk and dairy products, lean meats, cold cuts and sausages, lean and fatty fish, seafood, seed oils other than olive oil, precooked foods, stimulant drinks and alcoholic beverages. In the case of alcoholic beverages, a third of all participants reported a decrease in their consumption, with this reduction being greatest among the youngest group, where there was a 50\% drop.

Table 6 shows the different relationships between the assessment of eating and the variables: modified weight, level of physical activity, amount of food consumed and modified sleep. When diet was assessed in relation to physical activity, there was a positive association ( $\mathrm{OR}=2.56,95 \% \mathrm{Cl}=1.96 ; 3.34$ ), i.e., people who were more physically active were two and a half times more likely to evaluate their diet positively. On the other hand, there was a negative association with regard to quantity eaten (OR= $0.60,95 \% \mathrm{Cl}=0.46 ; 0.78)$, meaning that eating was negatively valued among those who ate more food. The same degree of association holds for both the raw and adjusted data, in such a way that, when corrected for sex and educational level, the OR increased slightly in both cases, and the Cls remained virtually unchanged.

\section{DISCUSSION}

The global COVID-19 pandemic led to home isolation measures in many parts of the world. Changes in dietary patterns have been identified as a result of this lockdown, as well as lifestyle changes that affect sleep and physical activity. As in other studies, our data show that a small number of people spent the lockdown alone, which is consistent with other studies [16, 22, 23]. Age is shown to be a determining factor in the changes observed; around $50 \%$ of those surveyed who are of working age have seen their income reduced as a result of the shutdown of non-essential activity, as demonstrated by the National Statistics Institute in Spain [24, 25]. With the closure of non-essential activity and the shift to online education, few people had to leave home to go to their workplace. This affected the middle-aged population to the greatest extent, as they have more stable jobs, similarly to that reported in other work [17].

In terms of body weight, most of the participants claim to have undergone changes, coinciding with that described by Cancello et al. [16] in their study on an Italian population. In this sense, the population over 35 years of age considers that they have undergone fewer changes in their eating habits. The Kantar report [26] shows that as the weeks of lockdown passed, consumers became more aware of the importance of healthier, waste-free eating and gained an interest in getting into the kitchen to make healthy dishes, results that are consistent with those from another study conducted in France over the same weeks [27]. In view of our data, it is possible to think that the same phenomenon occurred; a progressive awareness of the importance of food. However, we could also consider that the preparation of healthy dishes served as an escape and a way to keep busy [16, 23, 28, 29].

On a general level, the participants consumed more food as they had more time, quicker access to food and greater stress levels [7, 30-32]. To cope with this high demand for products, all links in the food production chain had to adapt rapidly [4, 33]. Related to this higher level of consumption is the group of 18-35year olds who claimed to have increased the variety in their diets; they are the most irregular in terms of schedule, and they are the group who showed the greatest increase in the number of meals eaten every day. The Ministry of Agriculture, Fisheries and Food
(MAPA) described increased food consumption in Spanish households over the lockdown weeks compared to the same time last year [4], although it did not indicate whether there were agelinked differences. Coinciding with these data, half of our participants snacked more between meals, similarly to that reported in other research [34]; however, in the study by Rodríguez-Pérez et al. [35] also involving a Spanish population, almost half of the participants claimed to have maintained their habits, showing similar patterns to the pre-confinement stage. As for the type of food consumed, almost a third of respondents increased their consumption of fresh food and reduced their purchase of packaged products, which are presented as less perishable and fast food served at home. This may be due to the fact that one of the few activities permitted was going shopping, combined with increased time spent on cooking and a certain fear of being infected by home deliverers [36, 37]. Indeed, in this sense, measures were established for the catering industry to limit the risk of contagion [38].

Around a quarter of the participants increased their consumption of food groups like cereals, tubers, legumes, meats and cold cuts, as well as dairy products, figures that are in line with those published in the Smart Agrifood report [33]. This growth was higher in the 18-35 age group, as reflected in another study conducted on a Polish population [34]. In addition, almost half of the participants increased their intake of so-called comfort foods (sweets and pastries), just as in other populations studied [30], and almost a third increased their consumption of nuts, information that is reflected in the MAPA report [4]. At the same time, we observed a decrease in the consumption of seafood, especially in the 36-65 age group, and among the youngest, we detected a more pronounced decrease in the consumption of precooked foods, stimulant and alcoholic beverages, as well as cereals and whole-grain products. Although purchases of alcohol and spirits rose slightly, this is far less than the number of beverages purchased for consumption outside the home in the prepandemic period, coinciding with that reported in other studies $[4,39,40]$. In our study, the greatest drop in consumption was seen in the 18-35-year olds. This trend change could be explained by the impossibility of having interpersonal relationships and doing leisure activities outside the home. Overall, these findings are in line with those described by previous studies [16, 17, 34, 35] that describe decreased alcohol consumption in the general population.

On the other hand, more than half of the participants experienced changes in their sleep pattern, again consistent with the results described by other studies [16, 22, 27, 41-43], and which could be explained by changes in lifestyle, the situation of uncertainty generated by the impending economic recession and the social and health crisis in the country. In terms of age, the youngest participants had the most disturbed sleep patterns. In this sense, Mandelkorn et al. [44] in their study of adult populations in 49 countries found that people over 60 years of age are less likely to develop sleep disorders during periods of lockdown. Furthermore, they observed that the sample Spanish population had a much higher rate of sleep disorders than individuals in other countries, and that this could be related to a lack of physical activity.

In this context, when the State of Alarm was introduced [3], which prohibited people from leaving their homes for unjustified reasons, the $\mathrm{WHO}$, anticipating a decline in physical activity among citizens, published guidelines advocating the need to maintain daily physical activity during the lockdown period [14]. However, different studies [16, 22, 35, 43] show that during the pandemic few people actually increased their physical activity level. Indeed, studies such as that developed by Mattioli et al. [45] warn of the negative effects of not engaging in physical activity during the pandemic, including the appearance of metabolic disorders that increase cardiovascular risk, impaired aerobic 
Table 2. Habits before and during lockdown by age group.

\begin{tabular}{|c|c|c|c|c|}
\hline Variables & 18-35 years & $36-65$ years & $>65$ years & Total \\
\hline \multicolumn{5}{|c|}{ Weight change $p=0.001$} \\
\hline Yes & $321(55.2 \%)$ & $255(43.9 \%)$ & $5(0.9 \%)$ & 581 \\
\hline No & $160(47.8 \%)$ & $164(49.0 \%)$ & $11(3.3 \%)$ & 335 \\
\hline \multicolumn{5}{|c|}{ Has your sleep pattern changed? $p<0.001$} \\
\hline Yes & $492(60.1 \%)$ & $319(39.0 \%)$ & $7(0.9 \%)$ & 818 \\
\hline No & $128(39.8 \%)$ & $183(56.8 \%)$ & $11(3.4 \%)$ & 322 \\
\hline \multicolumn{5}{|c|}{ Do you find it more difficult to fall asleep? $p<0.05$} \\
\hline Yes & 409 (58.1\%) & $288(40.9 \%)$ & $7(1.0 \%)$ & 704 \\
\hline No & $211(49.1 \%)$ & $214(48.4 \%)$ & $11(2.5 \%)$ & 436 \\
\hline \multicolumn{5}{|c|}{ Assessment of your diet $p<0.001$} \\
\hline Better & $206(63.4 \%)$ & $119(36.6 \%)$ & 0 & 325 \\
\hline Worse & $229(58.3 \%)$ & $164(41.7 \%)$ & 0 & 393 \\
\hline The same & $185(43.8 \%)$ & 219 (51.9\%) & $18(4.3 \%)$ & 422 \\
\hline \multicolumn{5}{|c|}{ Level of physical activity $p<0.001$} \\
\hline Better & $273(71.1 \%)$ & $109(28.4 \%)$ & $2(0.5 \%)$ & 384 \\
\hline Worse & $167(45.3 \%)$ & $196(53.1 \%)$ & $6(1.6 \%)$ & 369 \\
\hline The same & $180(46.5 \%)$ & $197(50.9 \%)$ & $10(2.6 \%)$ & 387 \\
\hline \multicolumn{5}{|c|}{ Amount of food $p<0.001$} \\
\hline More & $286(55.2 \%)$ & $231(44.6 \%)$ & $1(0.2 \%)$ & 518 \\
\hline Less & $94(64.4 \%)$ & $50(34.2 \%)$ & $2(1.4 \%)$ & 146 \\
\hline The same & $240(50.4 \%)$ & $221(46.4 \%)$ & $15(3.2 \%)$ & 476 \\
\hline \multicolumn{5}{|c|}{ Variety of food $p=0.004$} \\
\hline More & $271(60.4 \%)$ & $174(38.8 \%)$ & $4(0.9 \%)$ & 449 \\
\hline Less & $116(55.8 \%)$ & $88(42.3 \%)$ & $4(1.9 \%)$ & 208 \\
\hline The same & $233(48.2 \%)$ & $240(49.7 \%)$ & $10(2.1 \%)$ & 483 \\
\hline \multicolumn{5}{|c|}{ Regularity of schedules $p<0.001$} \\
\hline More & $172(54.3 \%)$ & $143(45.1 \%)$ & $2(0.6 \%)$ & 317 \\
\hline Less & $194(67.1 \%)$ & $95(32.9 \%)$ & 0 & 289 \\
\hline The same & $254(47.6 \%)$ & $264(49.4 \%)$ & $16(3.0 \%)$ & 534 \\
\hline \multicolumn{5}{|c|}{ Number of meals per day $p<0.001$} \\
\hline More & $201(58.4 \%)$ & $141(41.0 \%)$ & $2(0.6 \%)$ & 344 \\
\hline Less & $107(74.3 \%)$ & $36(25.0 \%)$ & $1(0.7 \%)$ & 144 \\
\hline The same & $312(47.9 \%)$ & $325(49.8 \%)$ & $15(2.3 \%)$ & 652 \\
\hline \multicolumn{5}{|c|}{ Snacking between meals $p<0.001$} \\
\hline More & $263(52.7 \%)$ & $233(46.7 \%)$ & $3(0.6 \%)$ & 499 \\
\hline Less & $147(66.8 \%)$ & $71(32.3 \%)$ & $2(0.9 \%)$ & 220 \\
\hline The same & $210(49.9 \%)$ & $198(47.0 \%)$ & $13(3.1 \%)$ & 421 \\
\hline \multicolumn{5}{|c|}{ Fresh food consumption $p=0.001$} \\
\hline More & $213(62.3 \%)$ & $129(37.7 \%)$ & 0 & 342 \\
\hline Less & $102(51.8 \%)$ & $90(45.7 \%)$ & $5(2.5 \%)$ & 197 \\
\hline The same & $305(50.7 \%)$ & $283(47.1 \%)$ & $13(2.2 \%)$ & 601 \\
\hline \multicolumn{5}{|c|}{ Packaged food consumption $p=0.036$} \\
\hline More & $124(55.9 \%)$ & $93(41.9 \%)$ & $5(2.3 \%)$ & 222 \\
\hline Less & $195(58.0 \%)$ & $141(42.0 \%)$ & 0 & 336 \\
\hline The same & 301 (51.7\%) & $268(46.0 \%)$ & $13(2.3 \%)$ & 582 \\
\hline \multicolumn{5}{|c|}{ Fast food consumption at home $p<0.001$} \\
\hline More & $24(63.2 \%)$ & $14(36.8 \%)$ & 0 & 38 \\
\hline Less & 457 (58.6\%) & 319 (40.9\%) & $4(0.5 \%)$ & 780 \\
\hline The same & 139 (43.2\%) & 169 (52.5\%) & $14(4.3 \%)$ & 322 \\
\hline
\end{tabular}

Table 3. Frequency of consumption of drinks and carbohydratecontaining foods according to age group.

18-35 years 36-65 years >65 years Total Cereals and derivatives (bread, pasta, rice) $p<0.001$

$\begin{array}{lllll}\text { Not consumed } & 12(33.3 \%) & 20(55.6 \%) & 4(11.1 \%) & 36 \\ \text { More } & 182(58.1 \%) & 127(40.6 \%) & 4(1.3 \%) & 313 \\ \text { Less } & 91(66.4 \%) & 45(32.8 \%) & 1(0.7 \%) & 137 \\ \text { The same } & 335(51.2 \%) & 310(47.4 \%) & 9(1.4 \%) & 654 \\ \text { Cereals and whole-grain derivatives } & p<0.001 & & \\ \text { Not consumed } & 112(47.3 \%) & 116(48.9 \%) & 9(3.8 \%) & 237 \\ \text { More } & 107(59.8 \%) & 72(40.2 \%) & 0 & 179 \\ \text { Less } & 121(63.0 \%) & 70(36.5 \%) & 1(0.5 \%) & 192 \\ \text { The same } & 280(52.6 \%) & 244(45.9 \%) & 8(1.5 \%) & 532\end{array}$

Sweets and pastries (including breakfast cereals, chocolate and biscuits) $p<$ 0.05

\begin{tabular}{|c|c|c|c|c|}
\hline Not consumed & $103(50.7 \%)$ & $94(46.3 \%)$ & $6(3.0 \%)$ & 203 \\
\hline More & $236(54.5 \%)$ & $194(44.8 \%)$ & $3(0.7 \%)$ & 433 \\
\hline Less & $148(64.3 \%)$ & $78(33.9 \%)$ & $4(1.7 \%)$ & 230 \\
\hline The same & $133(48.5 \%)$ & $136(49.6 \%)$ & $5(1.8 \%)$ & 274 \\
\hline \multicolumn{5}{|c|}{ Fruit juices (including natural) $p=0.062$} \\
\hline Not consumed & $164(54.8 \%)$ & $127(42.5 \%)$ & $8(2.7 \%)$ & 299 \\
\hline More & $158(59.6 \%)$ & $105(39.6 \%)$ & $2(0.8 \%)$ & 265 \\
\hline Less & $87(56.5 \%)$ & $67(43.5 \%)$ & 0 & 154 \\
\hline The same & $211(50.0 \%)$ & $203(48.1 \%)$ & $8(1.9 \%)$ & 422 \\
\hline \multicolumn{5}{|c|}{ Vegetables and salad $p=0.104$} \\
\hline Not consumed & $13(72.2 \%)$ & $5(27.8 \%)$ & 0 & 18 \\
\hline More & $233(59.1 \%)$ & $157(39.8 \%)$ & $4(1.0 \%)$ & 394 \\
\hline Less & 77 (53.1\%) & $64(44.1 \%)$ & $4(2.8 \%)$ & 145 \\
\hline The same & $297(50.9 \%)$ & $276(47.3 \%)$ & $10(1.7 \%)$ & 583 \\
\hline \multicolumn{5}{|c|}{ Potatoes $p<0.001$} \\
\hline Not consumed & $8(21.6 \%)$ & $29(79.4 \%)$ & 0 & 37 \\
\hline More & $224(60.1 \%)$ & $146(39.1 \%)$ & $3(0.8 \%)$ & 373 \\
\hline Less & $56(55.4 \%)$ & $44(43.6 \%)$ & $1(1.0 \%)$ & 101 \\
\hline The same & $332(52.8 \%)$ & $283(45.0 \%)$ & $14(2.2 \%)$ & 629 \\
\hline \multicolumn{5}{|l|}{ Pulses $p=0.018$} \\
\hline Not consumed & $30(61.2 \%)$ & $19(38.8 \%)$ & 0 & 49 \\
\hline More & $197(59.3 \%)$ & $130(39.2 \%)$ & $5(1.5 \%)$ & 332 \\
\hline Less & $72(64.3 \%)$ & 39 (34.8\%) & $1(0.9 \%)$ & 112 \\
\hline The same & $321(49.6 \%)$ & $314(48.5 \%)$ & $12(1.9 \%)$ & 647 \\
\hline \multicolumn{5}{|c|}{ Soft drinks $p=0.077$} \\
\hline Not consumed & $241(55.4 \%)$ & $183(42.1 \%)$ & $11(2.5 \%)$ & 435 \\
\hline More & $112(57.7 \%)$ & $81(41.8 \%)$ & $1(0.5 \%)$ & 194 \\
\hline Less & $118(56.7 \%)$ & $86(41.3 \%)$ & $4(2.0 \%)$ & 208 \\
\hline The same & $149(49.2 \%)$ & $152(50.2 \%)$ & $2(0.6 \%)$ & 303 \\
\hline \multicolumn{5}{|c|}{ Stimulant drinks (with caffeine, theine and ginseng) $p<0.05$} \\
\hline Not consumed & $330(57.5 \%)$ & $231(40.2 \%)$ & $13(2.3 \%)$ & 574 \\
\hline More & $58(47.5 \%)$ & $64(52.5 \%)$ & 0 & 122 \\
\hline Less & $109(59.3 \%)$ & 74 (39.6\%) & $4(2.1 \%)$ & 187 \\
\hline The same & $123(47.9 \%)$ & $133(51.8 \%)$ & $1(0.4 \%)$ & 257 \\
\hline \multicolumn{5}{|c|}{ Alcoholic beverages $p<0.001$} \\
\hline Not consumed & $193(56.8 \%)$ & $138(40.6 \%)$ & $9(2.6 \%)$ & 340 \\
\hline More & $72(38.9 \%)$ & $112(60.5 \%)$ & $1(0.5 \%)$ & 185 \\
\hline Less & 265 (73.2\%) & 93 (25.7\%) & 4 (1.1\%) & 362 \\
\hline The same & 90 (35.6\%) & 159 (62.8\%) & $4(1.6 \%)$ & 253 \\
\hline
\end{tabular}


Table 4. Frequency of consumption of protein-based food according to age group.

\begin{tabular}{|c|c|c|c|c|}
\hline & 18-35 years & $36-65$ years & $>65$ years & Total \\
\hline \multicolumn{5}{|c|}{ Milk and dairy products (yoghurt, cheese) $p<0.05$} \\
\hline Not consumed & $46(55.4 \%)$ & $36(43.4 \%)$ & $1(1.2 \%)$ & 83 \\
\hline More & $185(64.7 \%)$ & 99 (34.6\%) & $2(0.7 \%)$ & 286 \\
\hline Less & $55(58.5 \%)$ & $38(40.4 \%)$ & $1(1.1 \%)$ & 94 \\
\hline The same & $334(49.3 \%)$ & $329(48.6 \%)$ & $14(2.1 \%)$ & 677 \\
\hline \multicolumn{5}{|c|}{ Dairy-type beverages (soy, almond, oatmeal) $p=0.401$} \\
\hline Less & $49(57.6 \%)$ & $35(41.2 \%)$ & $1(1.2 \%)$ & 85 \\
\hline The same & $196(52.3 \%)$ & $175(46.7 \%)$ & $4(1.1 \%)$ & 375 \\
\hline \multicolumn{5}{|c|}{ Dairy desserts (custard, flan, rice pudding, etc.) $p<0.05$} \\
\hline Not consumed & $220(50.6 \%)$ & $166(42.2 \%)$ & $7(1.8 \%)$ & 393 \\
\hline Not consumed & 77 (63.1\%) & 45 (36.9\%) & 0 & 122 \\
\hline More & $121(60.5 \%)$ & $76(38.0 \%)$ & $3(1.5 \%)$ & 200 \\
\hline Less & $96(57.5 \%)$ & $69(41.3 \%)$ & $2(1.2 \%)$ & 167 \\
\hline The same & $326(50.1 \%)$ & $312(47.9 \%)$ & $13(2.0 \%)$ & 651 \\
\hline \multicolumn{5}{|c|}{ Lean meats (chicken, turkey, rabbit) $p<0.05$} \\
\hline Not consumed & $41(74.5 \%)$ & $14(25.5 \%)$ & 0 & 55 \\
\hline More & $156(58.9 \%)$ & $106(40.0 \%)$ & $3(1.1 \%)$ & 265 \\
\hline Less & $67(65.7 \%)$ & $34(33.3 \%)$ & $1(1.0 \%)$ & 102 \\
\hline The same & $356(49.6 \%)$ & $348(48.5 \%)$ & $14(1.9 \%)$ & 718 \\
\hline \multicolumn{5}{|c|}{ Sausages and cold cuts $p<0.05$} \\
\hline More & $143(62.4 \%)$ & $85(37.1 \%)$ & $1(0.4 \%)$ & 229 \\
\hline Less & $117(50.2 \%)$ & $110(47.2 \%)$ & $6(2.6 \%)$ & 233 \\
\hline The same & $281(49.0 \%)$ & $282(49.2 \%)$ & $10(1.7 \%)$ & 573 \\
\hline \multicolumn{5}{|c|}{ Lean and semi-fatty fish (hake, cod, monkfish, gilt-head bream, sole) $p<0.001$} \\
\hline Not consumed & $80(82.5 \%)$ & $17(17.5 \%)$ & 0 & 97 \\
\hline More & $159(62.8 \%)$ & $91(36.0 \%)$ & $3(1.2 \%)$ & 253 \\
\hline Less & $113(48.1 \%)$ & $116(49.4 \%)$ & $6(2.6 \%)$ & 235 \\
\hline The same & $268(48.3 \%)$ & $278(50.1 \%)$ & $9(1.6 \%)$ & 555 \\
\hline \multicolumn{5}{|l|}{ Seafood $p<0.001$} \\
\hline Not consumed & $194(68.1 \%)$ & 87 (30.5\%) & $4(1.4 \%)$ & 285 \\
\hline More & $56(54.9 \%)$ & $44(43.1 \%)$ & $2(2.0 \%)$ & 102 \\
\hline Less & $140(42.3 \%)$ & $186(56.2 \%)$ & $5(1.5 \%)$ & 331 \\
\hline The same & $230(54.5 \%)$ & $185(43.8 \%)$ & $7(1.7 \%)$ & 422 \\
\hline \multicolumn{5}{|l|}{ Eggs $p=0.594$} \\
\hline Not consumed & $16(57.1 \%)$ & $12(42.9 \%)$ & 0 & 28 \\
\hline More & $220(55.0 \%)$ & $175(43.8 \%)$ & $5(1.2 \%)$ & 400 \\
\hline Less & $46(63.0 \%)$ & 25 (34.2\%) & $2(2.8 \%)$ & 73 \\
\hline The same & 338 (52.9\%) & $290(45.4 \%)$ & 11 (1.7\%) & 639 \\
\hline
\end{tabular}


capacity, insulin resistance and decreased muscle performance. However, despite the low expectations, in our study we found that more than two thirds of the respondents maintained or increased their physical activity, and similar values were found in a study of an Italian population, where participants who already engaged in sport prior to lockdown increased the frequency of their training [17]. In addition, in our study we found that the increase in physical activity was significantly higher among the younger age group, coinciding with that described by Pérez-Rodrigo et al. [46] in their study on a Spanish population, in which they observed greater physical activity levels during lockdown among participants aged between 18 and 34. Another study, conducted in

Table 5. Frequency of consumption of fat-containing foods according to age group.

\begin{tabular}{|c|c|c|c|c|}
\hline & 18-35 years & 36-65 years & $>65$ years & Total \\
\hline \multicolumn{5}{|l|}{ Olive oil $p=0.381$} \\
\hline Not consumed & $5(33.3 \%)$ & $10(66.7 \%)$ & 0 & 15 \\
\hline More & $159(59.3 \%)$ & $105(39.2 \%)$ & $4(1.5 \%)$ & 268 \\
\hline Less & $28(51.9 \%)$ & $25(46.3 \%)$ & $1(1.9 \%)$ & 54 \\
\hline The same & $428(53.3 \%)$ & $362(45.1 \%)$ & $13(1.6 \%)$ & 803 \\
\hline \multicolumn{5}{|c|}{ Other seed oils (sunflower) and fats (butter or margarine) $p<0.05$} \\
\hline Not consumed & $192(54.7 \%)$ & $146(41.6 \%)$ & $13(3.7 \%)$ & 351 \\
\hline More & $91(56.5 \%)$ & $69(42.9 \%)$ & $1(0.6 \%)$ & 161 \\
\hline Less & $84(60.9 \%)$ & $52(37.7 \%)$ & $2(1.4 \%)$ & 138 \\
\hline The same & $253(51.6 \%)$ & $235(48.0 \%)$ & $2(1.4 \%)$ & 490 \\
\hline \multicolumn{5}{|c|}{ Precooked foods $p<0.05$} \\
\hline Not consumed & $176(48.6 \%)$ & $177(48.9 \%)$ & $9(2.5 \%)$ & 362 \\
\hline More & $87(61.3 \%)$ & $53(37.3 \%)$ & $2(1.4 \%)$ & 142 \\
\hline Less & $195(62.3 \%)$ & $114(36.4 \%)$ & $4(1.3 \%)$ & 313 \\
\hline The same & $162(50.2 \%)$ & $158(48.9 \%)$ & $3(0.9 \%)$ & 323 \\
\hline \multicolumn{5}{|c|}{ Savoury snacks $p=0.946$} \\
\hline Not consumed & 139 (53.9\%) & $114(44.2 \%)$ & $5(1.9 \%)$ & 258 \\
\hline More & $179(54.7 \%)$ & $143(43.7 \%)$ & $5(1.5 \%)$ & 327 \\
\hline Less & $118(57.3 \%)$ & $86(41.7 \%)$ & $2(1.0 \%)$ & 206 \\
\hline The same & 184 (52.7\%) & 159 (45.6\%) & 6 (1.7\%) & 349 \\
\hline
\end{tabular}

northern Italy, concluded that people over 30 years of age were less likely to increase their physical activity during lockdown [16].

Numerous studies have found an association between diet, physical activity and body weight control [31, 47, 48]. In our case, there was a direct relationship between a healthy diet and the practice of regular physical activity. This finding is reflected by Flanagan et al. [49], who reported that study subjects who exhibited less healthy eating during lockdown had more sedentary behaviour. Pérez-Rodrigo et al. [46] showed how people who increased their physical activity were three times more likely to reduce their food intake.

The strengths of our study include the online survey, which allowed us to reach a large number of people quickly, at a time when most of the population could not leave their homes. In addition, the results are stratified by age group, which provides a clearer picture of eating behaviour in these populational groups. The limitations of the study include the non-random sampling technique employed to reach the participants. In addition, the majority of the participants were women, something which is very common in research conducted during lockdown [23, 41]. As this was an online survey, it was not possible to find out further details related to the participants' answers.

In conclusion, our results show that, during the lockdown period, study participants from 18 to 35 years of age increased both their physical activity levels and their consumption of fresh food; they also decreased their consumption of fast food at home and reduced their overall alcohol consumption. In the group of over 65 s, there were no changes in food consumption or routine despite the lockdown, and we can state that this social group has consolidated habits. Our findings suggest that, in the current social and health crisis, the citizens in southern Spain have become aware of how important maintaining appropriate lifestyles is in staying healthy, a trend that should be used by health authorities to promote strategies and interventions, either in health centres or through the use of digital tools, which allow greater adherence to healthy lifestyle habits, as it could have a positive impact on well-being physical, social and mental of the citizens before possible future home lockdown.

\section{DATA AVAILABILITY}

Due to the sensitive nature of the questions asked in this study, survey respondents were assured that raw data would remain confidential and would not be shared. Data not available/the data that have been used are confidential.

Table 6. Based on food assessment (less or the same vs. more).

\begin{tabular}{|c|c|c|c|c|c|c|}
\hline Variable & $n$ & $\%$ & OR & $95 \% \mathrm{Cl}$ & $O^{a}$ & $95 \% \mathrm{Cl}$ \\
\hline \multicolumn{7}{|c|}{ Modified weight } \\
\hline Yes & 502 & 72.5 & 1 & & & \\
\hline No & 313 & 69.9 & 0.88 & $0.68 ; 1.14$ & 0.89 & $0.68 ; 1.16$ \\
\hline \multicolumn{7}{|c|}{ Level of physical activity } \\
\hline Less-same & 591 & 78.2 & 1 & & & \\
\hline More & 224 & 58.3 & $2.56 * * *$ & $1.96 ; 3.34$ & $2.63 * * *$ & $2.01 ; 3.45$ \\
\hline More & 399 & 77.0 & $0.60 * * *$ & $0.46 ; 0.78$ & $0.61 * * *$ & $0.47 ; 0.79$ \\
\hline \multicolumn{7}{|c|}{ Modified sleep } \\
\hline Yes & 577 & 70.5 & 1 & & & \\
\hline No & 238 & 73.9 & 1.18 & $0.89 ; 1.58$ & 1.21 & $0.90 ; 1.62$ \\
\hline
\end{tabular}

Less or the same was taken as the reference. The data are presented as the odds ratio (OR) with $95 \%$ confidence intervals (Cl) using a logistic regression model. ${ }^{* * *} p<0.001$.

${ }^{\mathrm{a} O R}$ adjusted for sex and educational level. 


\section{REFERENCES}

1. World Health Organization (WHO). Listings of WHO's response to COVID-19. 2020. https://www.who.int/es/news/item/29-06-2020-covidtimeline. Accessed 15 Feb 2021.

2. World Health Organization (WHO). WHO Coronavirus Disease (COVID-19) Dashboard. 2020. https://covid19.who.int/. Accessed 17 Feb 2021.

3. Boletín Oficial del Estado (BOE). Real Decreto 463/2020, de 14 de marzo, por el que se declara el estado de alarma para la gestión de la situación de crisis sanitaria ocasionada por el COVID-19. 2020. https://www.boe.es/buscar/doc. php?id=BOE-A-2020-3692. Accessed 22 Jan 2021.

4. Ministerio de Agricultura PYA Informe del Consumo Alimentario en España 2019. Efecto del estado de alarma. Datos preliminares 2020. 2020. https://www.mapa. gob.es/es/alimentacion/temas/consumo-tendencias/presentaciondatosconsumo_ vf ok tcm30-540247.pdf. Accessed 28 Nov 2020.

5. Brooks SK, Webster RK, Smith LE, Woodland L, Wessely S, Greenberg N, et al. The psychological impact of quarantine and how to reduce it: rapid review of the evidence. Lancet. 2020;395:912-20. https://doi.org/10.1016/s0140-6736(20) 30460-8.

6. Fawaz M, Samaha A. COVID-19 quarantine: post-traumatic stress symptomatology among Lebanese citizens. Int J Soc Psychiatry. 2020;66:666-74. https://doi. org/10.1177/0020764020932207.

7. Yau YHC, Potenza MN. Stress and eating behaviors. Minerva Endocrinol. 2013:38:255-67.

8. Leng G, Adan RAH, Belot M, Brunstrom JM, de Graaf K, Dickson SL, et al. The determinants of food choice. Proc Nutr Soc. 2017;76:316-27. https://doi.org/ 10.1017/S002966511600286X.

9. Ministerio de Agricultura PYA. Los hogares españoles estabilizan el consumo de alimentos con respecto a la semana anterior. 2020. https://www.mapa.gob.es/es/ prensa/ultimas-noticias/los-hogares-espa\%C3\%B1oles-estabilizan-el-consumode-alimentos-con-respecto-a-la-semana-anterior/tcm:30-537932. Accessed 12 Dec 2020.

10. Ministerio de Agricultura PYA. El consumo de helados en los hogares sube el $5,8 \%$ con respecto al año anterior. 2020. https://www.mapa.gob.es/ca/prensa/ ultimas-noticias/el-consumo-de-helados-en-los-hogares-sube-el-58-conrespecto-al-a\%C3\%B1o-anterior-/tcm:34-543007. Accessed 21 Nov 2020.

11. Agencia Española de Seguridad Alimentaria y Nutrición. Plan de colaboración para la mejora de la composición de los alimentos y bebidas y otras medidas 2020. 2020 https://www.aesan.gob.es/AECOSAN/web/nutricion/seccion/plan_colaboracion.htm. Accessed 20 Nov 2020.

12. World Health Organization (WHO). Food and nutrition tips during self-quarantine 2020. https://www.euro.who.int/en/health-topics/health-emergencies/coronaviruscovid-19/publications-and-technical-guidance/food-and-nutrition-tips-during-selfquarantine. Accessed 22 Jan 2021.

13. Buzzachera CF, Correale L, Liberali G. Physical activity and cardiovascular health. In: Govoni S, Politi P, Vanoli E, editors. Brain and heart dynamics. Gewerbestrasse: Springer Nature Switzerland AG; 2020. p. 871-80.

14. World Health Organization (WHO). Coronavirus disease (COVID-19): staying active. 2020. https://www.who.int/emergencies/diseases/novel-coronavirus2019/question-and-answers-hub/q-a-detail/coronavirus-disease-covid-19staying-active. Accessed 20 Nov 2020.

15. Ammar A, Brach M, Trabelsi K, Chtourou H, Boukhris O, Masmoudi L, et al. Effects of COVID-19 home confinement on eating behaviour and physical activity: results of the ECLB-COVID19 International Online Survey. Nutrients. 2020;12:1583. https://doi.org/10.3390/nu12061583.

16. Cancello R, Soranna D, Zambra G, Zambon A, Invitti C. Determinants of the lifestyle changes during COVID-19 pandemic in the residents of Northern Italy. Int J Environ Res Public Health. 2020;17:6287. https://doi.org/10.3390/ ijerph17176287.

17. di Renzo L, Gualtieri $P$, Pivari $F$, Soldati $L$, Attinà $A$, Cinelli $G$, et al. Eating habits and lifestyle changes during COVID-19 lockdown: an Italian survey. J Transl Med. 2020;18:229. https://doi.org/10.1186/s12967-020-02399-5.

18. Ruíz J. Los factores definitorios de los grandes grupos de edad de la población: tipos, subgrupos y umbrales. Scr Nova: Rev electrónica de Geogría y Cienc Soc. 2005;9:181-204

19. Delgado-Losada ML. Psicología del desarrollo. In: Fundamentos de Psicología para ciencias sociales y de la salud. Médica Panamericana; 2015. p. 267-93.

20. Boletín Oficial del Estado (BOE). Real Decreto Legislativo 8/2015, de 30 de octubre, por el que se aprueba el texto refundido de la Ley General de la Seguridad Social. 2015. https://www.boe.es/buscar/pdf/2015/BOE-A-2015-11724consolidado.pdf. Accessed 20 Nov 2020.

21. Population (Spaniards/foreigners) since 1998 by age ( 3 age groups), sex and year. https://www.ine.es/jaxiPx/Tabla.htm?path=/t20/e245/p08/l0/\&file=01001. px\&L=1. Accessed 29 Jun 2021.

22. Górnicka M, Drywień ME, Zielinska MA, Hamułka J. Dietary and lifestyle changes during covid-19 and the subsequent lockdowns among polish adults: A cross- sectional online survey PLifeCOVID-19 study. Nutrients. 2020;12:2324. https://doi. org/10.3390/nu12082324.

23. Pérez-Rodrigo C, Gianzo Citores M, Hervás Bárbara G, Ruiz-Litago F, Casis Sáenz L, Aranceta-Bartrina J, et al. Changes in eating habits during lockdown period due to the COVID-19 pandemic in Spain. Rev Esp Nutr Comunitaria. 2020;26:28010. https://doi.org/10.14642/RENC.2020.26.2.5213.

24. Instituto Nacional de Estadística. Porcentaje de establecimientos que durante el estado de alarma han tenido que adoptar medidas referentes al empleo: Sectores de actividad. 2020. https://www.ine.es/jaxi/Datos.htm?path=/COVID/ice/p01//1/ \&file=01005.px. Accessed 5 Apr 2021.

25. Instituto Nacional de Estadística. Indicador de Confianza Empresarial (ICE). Módulo de opinión sobre el impacto de la COVID-19. Estado de alarma y segundo semestre de 2020. https://www.ine.es/daco/daco42/ice/ice_mod_covid_0320. pdf. Accessed 26 Apr 2021.

26. Kantar. El confinamiento lleva a récords en ticket medio. 2020. https://www. kantar.com/es/inspiracion/coronavirus/el-confinamiento-lleva-a-records-enticket-medio. Accessed 24 Jan 2021.

27. Rossinot H, Fantin R, Venne J. Behavioral changes during COVID-19 confinement in France: a web-based study. Int J Environ Res Public Health. 2020;17:8444. https://doi.org/10.3390/ijerph17228444.

28. Balluerka M, Gómez J, Hidalgo M, Gorostiaga M, Espada J, Padilla J, et al. Las consecuencias psicológicas de la COVID-19 y el confinamiento. Informe de Investigación; 2020.

29. Comunidad de Madrid. Hábitos saludables en época de pandemia. 2020. https:// www.comunidad.madrid/servicios/salud/habitos-saludables-epoca-pandemia. Accessed 22 Apr 2021.

30. Scarmozzino F, Visioli F. Covid-19 and the subsequent lockdown modified dietary habits of almost half the population in an Italian sample. Foods. 2020;9:675. https://doi.org/10.3390/foods9050675.

31. Zachary Z, Brianna F, Brianna L, Garrett P, Jade W, Alyssa D, et al. Self-quarantine and weight gain related risk factors during the COVID-19 pandemic. Obes Res Clin Pract. 2020;14:210-6. https://doi.org/10.1016/j.orcp.2020.05.004.

32. Sadler J, Thapaliya G, Jansen E, Aghababian A, Smith K, Carnell S. COVID-19 stress and food intake: protective and risk factors for stress-related palatable food intake in U.S. adults. Nutrients. 2021;13:901. https://doi.org/10.3390/nu13030901.

33. Fundación Europea para la Innovación: Smart AgriFood. Los supermercados y el sector retail se alinean para mejorar la respuesta ante el covid-19 en \#agrifoodbeatscoronavirus. 2020. http://smartagrifood.org/los-supermercados-y-elsector-retail-se-alinean-para-mejorar-la-respuesta-ante-el-covid-19-enagrifoodbeatscoronavirus/. Accessed 28 Apr 2021.

34. Sidor A, Rzymski P. Dietary choices and habits during COVID-19 lockdown: experience from Poland. Nutrients. 2020;12:1657. https://doi.org/10.3390/ nu12061657.

35. Rodríguez-Pérez C, Molina-Montes E, Verardo V, Artacho R, García-Villanova B, Guerra-Hernández EJ, et al. Changes in dietary behaviours during the COVID-19 outbreak confinement in the Spanish COVIDiet study. Nutrients. 2020;12:1730. https://doi.org/10.3390/nu12061730.

36. Abouzid M, El-Sherif DM, Eltewacy NK, Dahman N, Okasha S, Ghozy S, et al. Influence of COVID-19 on lifestyle behaviors in the Middle East and North Africa Region: a survey of 5896 individuals. J Transl Med. 2021;19:129. https://doi.org/ 10.1186/s12967-021-02767-9.

37. Wang X, Lei SM, Le S, Yang Y, Zhang B, Yao W, et al. Bidirectional influence of the COVID-19 pandemic lockdowns on health behaviors and quality of life among Chinese adults. Int J Environ Res Public Health. 2020;17:5575. https://doi.org/ 10.3390/ijerph17155575.

38. FAO and WHO. COVID-19 and food safety: guidance for food businesses: interim guidance. 2020. https://doi.org/10.4060/ca8660en. Accessed 7 May 2021.

39. Ministerio de Agricultura. PYA Análisis de consumo alimentario del 27 de abril al 3 de mayo (datos provisionales). 2020. https://www.mapa.gob.es/es/prensa/ ultimas-noticias/los-hogares-espa\%C3\%B1oles-estabilizan-el-consumo-dealimentos-con-respecto-a-la-semana-anterior/tcm:30-537932. Accessed 20 Jan 2021.

40. Ministerio de Agricultura. PYA Análisis de consumo en el hogar del 20 al 26 de abril. 2020. https://www.mapa.gob.es/es/prensa/ultimas-noticias/los-hogaresespa\%C3\%B1oles-muestran-su-preferencia-por-el-consumo-de-productosfrescos--/tcm:30-537733. Accessed 20 Jan 2021.

41. Costi S, Paltrinieri S, Bressi B, Fugazzaro S, Rossi PG, Mazzini E. Poor sleep during the first peak of the SARS-CoV-2 pandemic: a cross-sectional study. Int J Environ Res Public Health. 2021;18:306. https://doi.org/10.3390/ijerph18010306.

42. Suso-Ribera C, Martín-Brufau R. How much support is there for the recommendations made to the general population during confinement? A study during the first three days of the covid-19 quarantine in Spain. Int J Environ Res Public Health. 2020;17:4382. https://doi.org/10.3390/ijerph17124382.

43. López-Moreno M, López MTI, Miguel M, Garcés-Rimón M. Physical and psychological effects related to food habits and lifestyle changes derived from covid-19 
home confinement in the Spanish population. Nutrients. 2020;12:3445. https:// doi.org/10.3390/nu12113445

44. Mandelkorn U, Genzer S, Choshen-Hillel S, Reiter J, Meira C, Hochner H, et al. Escalation of sleep disturbances amid the COVID-19 pandemic: a cross-sectional international study. J Clin Sleep Med. 2021;17:45-53. https://doi.org/10.5664/ jcsm. 8800 .

45. Mattioli AV, Sciomer S, Cocchi C, Maffei S, Gallina S. Quarantine during COVID-19 outbreak: changes in diet and physical activity increase the risk of cardiovascular disease. Nutr Metab Cardiovasc Dis. 2020;30:1409-17. https://doi.org/10.1016/j. numecd.2020.05.020.

46. Pérez-Rodrigo C, Gianzo Citores M, Hervás Bárbara G, Ruíz-Litago F, Casis Sáenz L, Arija $V$, et al. Patterns of change in dietary habits and physical activity during lockdown in Spain due to the COVID-19 pandemic. Nutrients. 2021;13:300. https://doi.org/10.3390/nu13020300.

47. Cheikh Ismail L, Osaili TM, Mohamad MN, Al Marzouqi A, Jarrar A, Zampelas A, et al. Assessment of eating habits and lifestyle during the coronavirus 2019 pandemic in the Middle East and North Africa region: a cross-sectional study. $\mathrm{Br} J$ Nutr. 2021;126:757-66. https://doi.org/10.1017/S0007114520004547.

48. Cheikh Ismail L, Osaili TM, Mohamad MN, Al Marzouqi A, Jarrar A, Abu Jamous D, et al. Eating habits and lifestyle during COVID-19 lockdown in the United Arab Emirates: a cross-sectional study. Nutrients. 2020;12:3314. https://doi.org/ 10.3390/nu12113314.

49. Flanagan EW, Beyl RA, Fearnbach SN, Altazan AD, Martin CK, Redman LM. The impact of COVID-19 stay-at-home orders on health behaviors in adults. Obesity. 2021;29:438-45. https://doi.org/10.1002/oby.23066.

\section{ACKNOWLEDGEMENTS}

The authors would like to extend their gratitude and acknowledgements to all study participants.

\section{AUTHOR CONTRIBUTIONS}

CFN-P, EG-J and JS-R designed research; CFN-P and ÁF-A conducted research; CFN-P provided the database; MÁM-A analysed data; CFN-P, EG-J and JS-R wrote the paper; EG-J had primary responsibility for final content. All authors read and approved the final manuscript.

\section{COMPETING INTERESTS}

The authors declare no competing interests.

\section{ETHICAL APPROVAL}

The Ethical Principles established by the World Medical Association (WMA) in the Declaration of Helsinki were followed in the development of this study. This study was also in line with current Spanish legislation, the General Data Protection Regulation and Organic Law 3/2018, of 5 December, on Personal Data Protection and the guarantee of digital rights.

\section{ADDITIONAL INFORMATION}

Correspondence and requests for materials should be addressed to Emilio GonzálezJiménez.

Reprints and permission information is available at http://www.nature.com/ reprints

Publisher's note Springer Nature remains neutral with regard to jurisdictional claims in published maps and institutional affiliations. 